\title{
Modification of Pumice Mineral and Its Use as Additive for Poly (Lactic Acid) Based Bio-Composite Materials
}

\author{
Ali Sinan DikE ${ }^{1}$ \\ ${ }^{1}$ Adana Alparslan Türkeş Bilim ve Teknoloji Üniversitesi, Mühendislik Fakültesi, Malzeme Mühendisligi Bölümü, Adana. \\ e-posta: asdike@atu.edu.tr.ORCID ID: http://orcid.org/0000-0001-6214-6070 \\ Geliş Tarihi: 12.09.2019 Kabul Tarihi: 05.02.2020
}

Keywords

Pumice; Poly (lactic acid); Bio-composites;

Extrusion; Polymer

composites

\begin{abstract}
In this study, pumice $(P)$ mineral was treated with silane in order to increase the compatibility for poly(lactic acid) (PLA) which is a fully biodegradable polymer widely used in packaging and outdoor applications. Neat and treated P powders were compounded with PLA at the concentrations of 5, 10, 15 and 20 wt\% by melt mixing process. Surface characteristics of $P$ samples were examined using infrared spectroscopy. Mechanical, water uptake, melt-flow and morphological properties of prepared composites were investigated by tensile and impact tests, water absorption test, melt flow rate test (MFR) and scanning electron microscopy (SEM) technique, respectively. Mechanical test results revealed that the highest increase in tensile strength and modulus values was obtained for $15 \mathrm{wt} \%$ of silanized $\mathrm{P}$ containing composite which are found as $4.5 \%$ and $40 \%$ increase, respectively. Addition of silane-treated $P$ into PLA resulted in an increase in impact strength of about $33 \%$ compared to samples containing that were not treated with silane with the same proportion of P. Impact strengths of composites increased with increasing P concentration. Silanized P filled composite gave slightly higher MFR values with respect to pristine $P$. Water absorption values of composites were found as about twofold higher than that of unfilled PLA. Composites containing silanized P exhibited lower water uptake values compared to untreated $P$ samples because of the hydrophobic character of silicon containing surfaces. SEM micro-images of composites displayed that more homogeneous dispersion in PLA matrix was taken place for silane treated $P$ particles than that of neat $P$ stem from the increase of adhesion between $\mathrm{P}$ and PLA surfaces after silanization process.
\end{abstract}

\section{Pomza Mineralinin Modifikasyonu ve Poli (Laktik Asit) Bazlı Biyo- Kompozit Malzemelerinde Eklenti Olarak Kullanımı}

Öz

Bu çalışmada, pomza (P) minerali, ambalaj ve dış ortam uygulamalarında sıkça kullanılan tamamen biyobozunur bir polimer olan poli (laktik asit) (PLA) ile uyumunu artırmak amacıyla silan ile muamele edilmiştir. Muamele edilen ve edilmeyen P tozları PLA ile eriyik karıştırma yöntemi ile ağırıkça yüzde 5, 10, 15 ve 20 konsantrasyonlarında eklenmiştir. P numunelerinin yüzey özellikleri infrared spektrofotometre kullanılarak incelenmiştir. Hazırlanan kompozitlerin mekanik, su alma, erime-akış ve

Anahtar kelimeler

Pomza; Poli (laktik asit); Biyo-kompozitler;

Ekstrüzyon; Polimer kompozitler morfolojik özellikleri sırasıyla çekme ve darbe testleri, su emme testi, erime akış hızı testi (MFR) ve taramalı elektron mikroskopi (SEM) teknikleri ile araştırılmışır. Mekanik test sonuçlarına göre, çekme dayanımı ve modülde en yüksek artışa \%15 silanlanmış P içeren kompozitte sırasıyla \%4,5 ve \%40 artış ile rastlanmıştır. PLA içine silan ile muamele edilmiş $\mathrm{P}$ eklenmesi, silan ile muamele edilmemiş ve aynı oranda $\mathrm{P}$ içeren numuneler ile kıyasla darbe dayanımında \%33 civarında artışa neden olmuştur. Kompozitlerin darbe dayanımları artan P konsantrasyonu ile artmıştır. Silanlanmış P eklenmiş kompozit, silanlanmamış $P$ eklenmiş kompozite göre bir miktar yüksek MFR değeri vermiştir. Kompozitlerin su emme değerleri eklentisiz PLA'dan yaklaşık iki kat fazla olarak bulunmuştur. Silikon içeren yüzeylerin su sevmeyen özelliğinden dolayı silanlanmış $\mathrm{P}$ içeren kompozitler, modifiyesiz $\mathrm{P}$ ile kıyaslandığında daha düşük su emme değerleri sergilemiştir. Kompozitlerin SEM mikro-resimleri göstermektedir ki; silanlama işleminden sonra P ile PLA arasında yapışma arttığı için silan ile muamele edilmiş P parçacıklarında edilmeyenlere göre daha homojen dağılım gerçekleşmiştir. 


\section{Introduction}

The scientific and industrial attentions for production of environmentally friendly materials has become trend topic due to the recent ecological restrictions. Bio-composites are developed for the main purpose of the replacement of conventional petroleum based composite materials. Biocomposites are chosen over conventional composites because of having advantages of weight reductions, easy fabrication, recyclable and biodegradable character. They have recently used in industrial areas including packaging, textile, automotive and outdoor applications thanks to described advantageous properties (Bismarck et al. 2006, Mohanty et al. 2002, Tayfun 2017a).

Poly (lactic acid) (PLA) is the most popular candidate among renewable polymers. This commercialized bio-polymer has ability to decrease of the disposal problem encountered in packaging applications (Bajpai et al. 2012, Weber et al. 2002). Investigations of additives for PLA is a trending topic because of bio-polymers having limitations including insufficient mechanical strength, low thermal stability and narrow processing window(Murariu and Dubois 2016, Rasal et al. 2010, Ren 2011).

Natural minerals are used as fillers for polymeric materials due to their low cost and easy to handle. Influence of mineral additives for plastics is related with some factors such as size, loading ratio, shape and interfacial compatibility with polymer matrix (Theberge 1982, Xanthos 2005). Enhancement of adhesion of mineral filler to polymer is important for fabrication of composite materials having required properties (Kanbur and Tayfun 2017, Metin et al.2004, Oktem and Tincer 1994, Rothon 2003).

Pumice mineral is obtained from volcanic eruption areas. Turkey has a large portion of pumice reserves among other countries such as Italia, Spain, Mexico, Chile, USA, Iceland, Greece and Indonesia. Nevsehir, Kars, Ankara, Afyon, Izmir and Kayseri are the main areas where Turkish pumice deposits are found (Bolen 2008, Elmastas 2012, Kul et al. 2017,
Yazicioglu et al. 2003). Because of pumice has a very porous structure, it is mainly used as light weight building materials. According to the literature, pumice was used as additive for polyethylene (Han et al. 2009), polypropylene (Kanbur and Tayfun 2018), polyvinyl alcohol (Jayakrishnan and Ramesan 2016), polyacrylonitrile (Yavuz et al. 2008), polyvinyl pyrolidone (Ramesan et al. 2016), polyaniline (Gok et al. 2006), polyphenylene sulphide (Sahin et al. 2013), and polyhydroxyethylmethacrylate (Akkaya 2013) matrices.

The aim of this study is development of biodegradable polymer composites by using pumice mineral as natural additive material. Mechanical, physical and morphological properties of pumice filled PLA bio-composites were investigated in order to demonstration of their possible use in industrial applications. Silanization process was applied to pumice powder for improvement of its compatibility to PLA matrix. Silane treated and pristine powder surfaces were characterized by infrared spectroscopy. Composites were produced using labscale extrusion and test samples were prepared by injection molding process. Tensile test, impact test, water absorption study, Melt flow rate measurement and scanning electron microscopy were performed in order to characterize the properties of composites.

\section{Materials and methods}

\subsection{Materials}

The commercial grade PLA was purchased from Natureworks LLC, USA with the trade name of Ingeo biopolymer $6100 \mathrm{D}$. It has a density of $1.24 \mathrm{~kg} / \mathrm{m}^{3}$ according to supplier. Pumice powder was obtained from Miner Mining Inc, Nevsehir, Nigde, Turkey. The avarage particle size of $P$ used in this study was 200 microns. Silane coupling agent, 3Aminopropyltriethoxysilane and reagent grade ethanol were obtained from Merck AG, Germany.

\subsection{Surface silanization of pumice}

During silanization process, pumice powder was mixed in 2 wt\% of 3-Aminopropyltriethoxysilane /ethanol solution for 100 minutes at room 
temperature. After several washings sample was dried at $80^{\circ} \mathrm{C}$ for 6 hours. Pristine and silane treated pumice samples were named as $P$ and $P(S)$, respectively.

\subsection{Production of composites}

Composite materials were fabricated using DSM Xplore micro-compounder at $210^{\circ} \mathrm{C}$ for 5 minutes. The mixing speed was preferred as $100 \mathrm{rpm}$. Unfilled PLA was mixed under the same processing conditions and named as PLA. Filling ratios of $\mathrm{P}$ and $P(S)$ were 5, 10, 15 and 20 wt\%. Test samples of were prepared using Daca Instruments microinjection molding machine at a barrel and mold temperatures of $210^{\circ} \mathrm{C}$ and $60^{\circ} \mathrm{C}$, respectively.

\subsection{Characterization methods}

Infrared spectroscopy (IR) technique in ATR mode (Bruker Optics, 66/S series) was performed to investigate the surface characteristics of pristine and silane treated $P$ powders. Tensile tests were carried out according to ASTM D638M-91a standard by Lloyd LR $30 \mathrm{~K}$ universal tensile testing device with $5 \mathrm{kN}$ load cell and crosshead speed of 5 $\mathrm{cm} / \mathrm{min}$. The tensile strength, tensile modulus and percentage strain values were recorded by testing at least five samples for each composition and taking the averages values. Impact test was done by Coesfeld material impact tester with the 4J pendulum using ASTM D256 standard procedure. At least five samples were used for each composition set, the average and standard deviation values were calculated during impact test. Melt flow rates (MFR) measurements were performed by Coesfeld meltfixer LT with the standard load of $5 \mathrm{~kg}$ at $210^{\circ} \mathrm{C}$ in accordance with ASTM D1238-79 standard. Test samples were conditioned and immersed in water bath at room temperature in 10 days during water absorption test using test route indicated in ASTMD570 standard. In order to perform scanning electron microscopy (SEM) analysis, the fractured surfaces of composites ontained from impact test were examined by FEI Quanta 400F FESEM scanning electron microscope for morphological characterization.

\section{Results and discussion}

\subsection{IR analysis}

IR spectrum of $P$ and $P(S)$ samples are shown in Figure 1. The peak centered at $1000 \mathrm{~cm}^{-1}$ is attributed to oxygen functionality (Dogan et al. 2016, Silverstein and Webster 2006) P (S) sample gave broader band for that oxygen related peak. The peaks seen at range of $600 \mathrm{~cm}^{-1}$ and $1000 \mathrm{~cm}^{-1}$ wavenumbers assign the $\mathrm{Si}-\mathrm{O}$ vibrations (Kilinc et al. 2019, Shokoohi et al. 2008, Yang et al. 2003). The spectra of $P(S)$ displayed higher intensity for these peaks due to forming silanol bonds at powder surface. These findings confirm that neat pumice surfaces were covered by silane coupling agent.

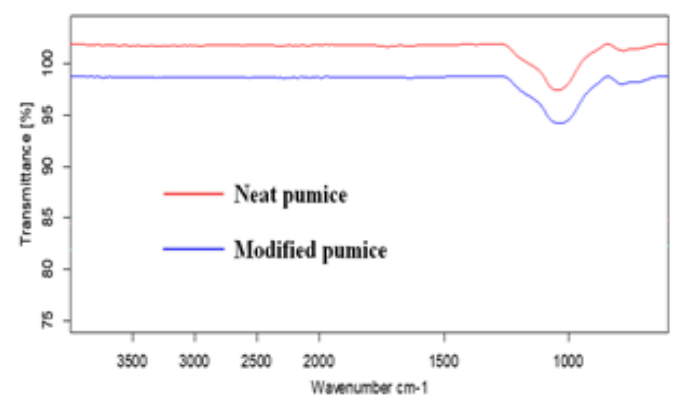

Figure 1. IR spectra of pumice samples

\subsection{Mechanical tests}

Mechanical test data of PLA and composites are listed in Table 1 and the tensile test curves are represented in Figure 2.

Impact strength results of unfilled PLA and composites can be seen from the last column of Table 1. Impact strength of PLA displayed reduction with $\mathrm{P}$ inclusions. Impact strength values of composites increased with the concentrations of $P$ and $\mathrm{P}(\mathrm{S})$. $\quad \mathrm{P}(\mathrm{S})$ containing composites gave nearly 2.5 points higher impact strength values compared to $P$ at the same concentrations. The highest impact strength was found for PLA-P (S) 20 sample among composites. These results may due to the improvement of adhesion between PLA and P phases by the formation of silane layer on the $P$ surface after treatment (Eselini et al. 2019, Hatipoglu et al. 2019).

It can be seen from Table 1 that tensile strength decreases with the addition of pumice at lower concentrations. 
Table 1. Mechanical test results

\begin{tabular}{lcccc}
\hline Samples & $\begin{array}{c}\text { Tensile Strength } \\
\left(\mathbf{N} / \mathbf{m}^{\mathbf{2}}\right)\end{array}$ & $\begin{array}{c}\text { Tensile Modulus } \\
(\mathbf{G P a})\end{array}$ & $\begin{array}{c}\text { Elongation at } \\
\text { Break (\%) }\end{array}$ & $\begin{array}{c}\text { Impact Strength } \\
\left(\mathbf{k J} / \mathbf{m}^{\mathbf{2}}\right)\end{array}$ \\
\hline PLA & $58.4 \pm 1.6$ & $1.0 \pm 0.1$ & $11.6 \pm 0.7$ & $11.6 \pm 0.4$ \\
PLA-P 5 & $53.6 \pm 1.2$ & $1.1 \pm 0.1$ & $8.5 \pm 0.4$ & $6.8 \pm 0.2$ \\
PLA-P 10 & $54.1 \pm 1.3$ & $1.1 \pm 0.1$ & $9.0 \pm 0.6$ & $7.5 \pm 0.3$ \\
PLA-P 15 & $56.0 \pm 1.7$ & $1.3 \pm 0.2$ & $8.7 \pm 0.5$ & $8.4 \pm 0.2$ \\
PLA-P 20 & $53.3 \pm 1.5$ & $1.2 \pm 0.2$ & $8.8 \pm 0.7$ & $9.0 \pm 0.3$ \\
PLA-P (S) 5 & $58.0 \pm 1.6$ & $1.2 \pm 0.1$ & $9.3 \pm 0.6$ & $9.3 \pm 0.3$ \\
PLA-P (S) 10 & $60.4 \pm 1.4$ & $1.3 \pm 0.2$ & $9.6 \pm 0.5$ & $10.1 \pm 0.4$ \\
PLA-P (S) 15 & $61.0 \pm 1.8$ & $1.4 \pm 0.1$ & $9.2 \pm 0.5$ & $11.2 \pm 0.3$ \\
PLA-P (S) 20 & $57.2 \pm 1.3$ & $1.3 \pm 0.1$ & $9.4 \pm 0.4$ & $11.9 \pm 0.3$ \\
\hline
\end{tabular}

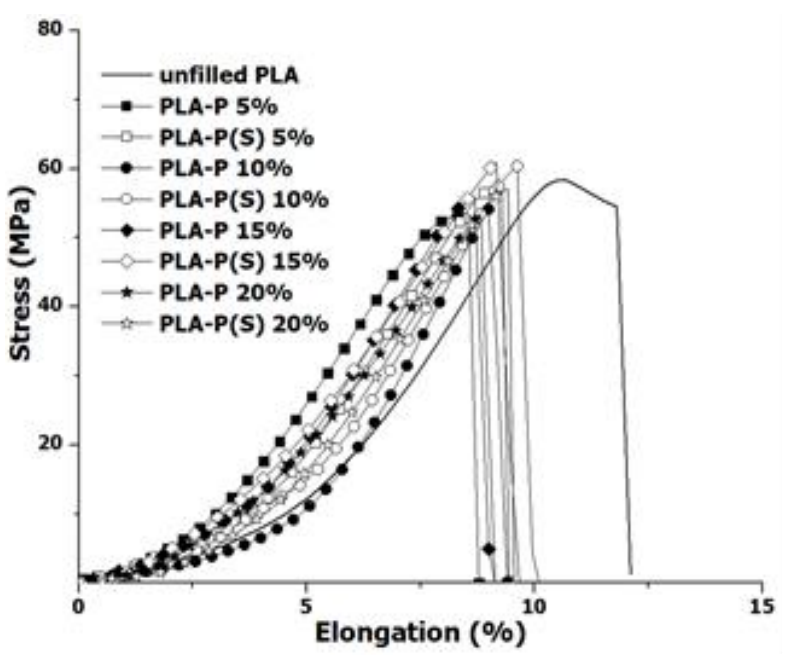

Figure 2. Tensile curves of PLA and composites

Further additions caused increase in strength values. The highest result was obtained at the filling ratio of 15 wt\% for both of $P$ and $P(S)$. $P(S)$ containing composites gave remarkably higher tensile strength values as compared with the same concentrations of $\mathrm{P}$. Improvement of adhesion between $\mathrm{P}(\mathrm{S})$ and PLA matrix may be the reason of this finding (Alghadi et al. 2020, Tayfun and Dogan 2016). Tensile modulus increases with the concentration. In contrast, elongation values showed decreasing trend by the addition of $P$ and $P$ (S). According to Figure 2, the highest elongation was obtained for unfilled PLA.

\subsection{Melt-flow rate}

According to MFR values shown in Figure 3, all of the MFR values are seen in a narrow range. This result indicates that processing of these composites can be performed practically in industrial scale production applications. Additions of $\mathrm{P}$ and $\mathrm{P}(\mathrm{S})$ led to increase for MFR value of unfilled PLA. MFR values displayed improvement with increase in concentration. Silane treated $P$ containing composites showed slightly higher MFR values as compared with pristine $P$ due to increase of compatibility between $\mathrm{P}(\mathrm{S}$ ) with polymer matrix ( $\mathrm{Ge}$ et al. 2009, Tayfun et al. 2017b, Tian and Tagaya 2007).

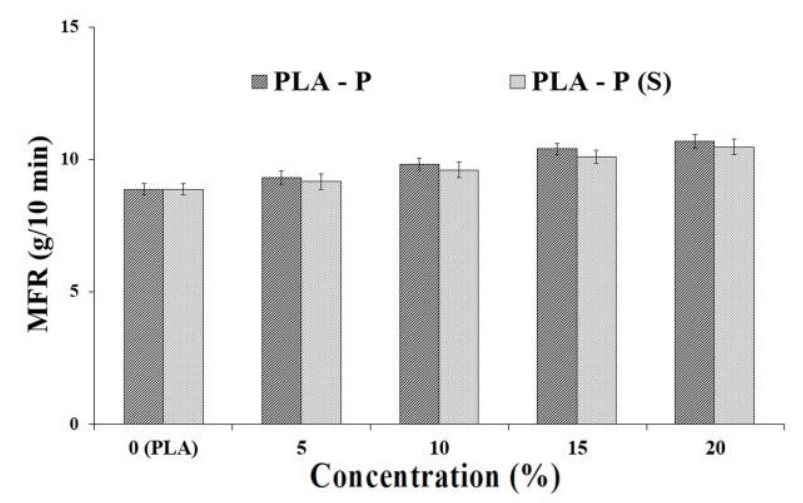

Figure 3. MFR results of PLA and composites

\subsection{Water absorption}

Water absorption test data of unfilled PLA and its composites for the time period of 15 days are listed in Table 2. The unfilled PLA sample reached to absorption value of about $1 \%$. Water uptake values of composites shifted to higher amounts with the increase of $\mathrm{P}$ concentration. $\mathrm{P}(\mathrm{S})$ filled composites exhibited relatively lower water absorption values than untreated $\mathrm{P}$ containing composites at their identical concentrations. This result caused from the hydrophobicity silane containing surface of treated P sample (Arbelaiz et al. 2005, Tayfun et al. 2016). 
Table 2. Water absorption test results

\begin{tabular}{lc}
\hline Samples & Water Absorption (\%) \\
\hline PLA & $0.9 \pm 0.1$ \\
PLA-P 5 & $1.7 \pm 0.1$ \\
PLA-P 10 & $2.0 \pm 0.2$ \\
PLA-P 15 & $2.5 \pm 0.1$ \\
PLA-P 20 & $2.9 \pm 0.1$ \\
PLA-P (S) 5 & $1.2 \pm 0.2$ \\
PLA-P (S) 10 $1.6 \pm 0.1$ \\
PLA-P (S) 15 & $2.1 \pm 0.2$ \\
PLA-P (S) 20 & $2.4 \pm 0.1$ \\
\hline
\end{tabular}

\subsection{Morphological characterization}

SEM micro-images of composites having their lowest (5\%) and the highest (20\%) concentrations are represented in Figure 4. Poor adhesion of pumice particles inside to PLA matrix can be easily seen from the SEM image of PLA-P 5 composite. On the other hand, the surface of $P(S)$ particles can be seen as surrounded by PLA matrix. Formations of agglomerates for pristine P particles into PLA was observed for higher concentrations. In contrast,

$P(S)$ particles showed homogeneous dispersion into PLA the matrix according to SEM image of PLA-P (S) 20 composite. These results prove that welldispersion of pumice particles were obtained for silanized $P$ samples thanks to the enhancement of adhesion between two phases.
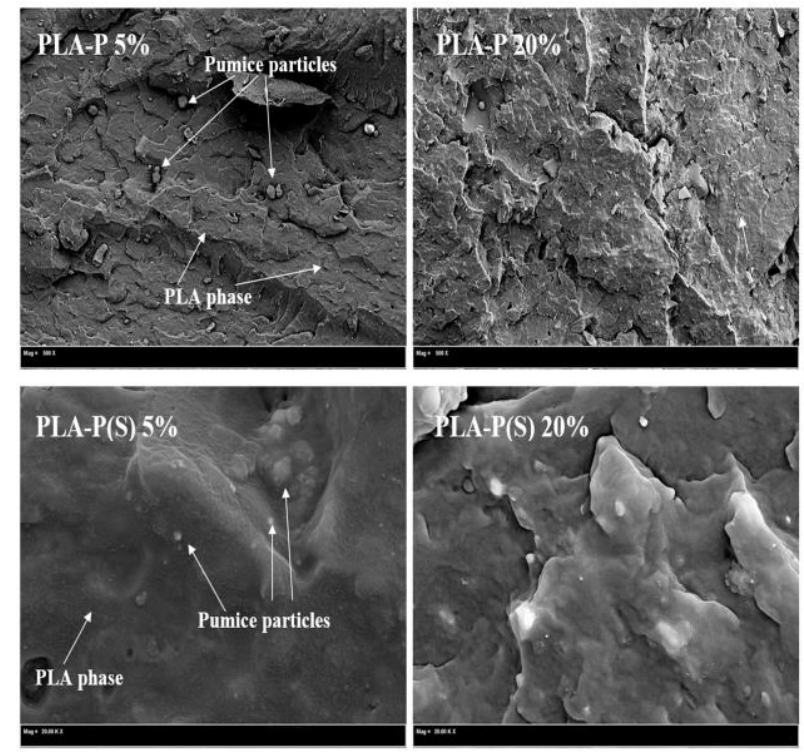

Figure 4. SEM micro-images of composites

\section{Conclusion}

In this study, influence of surface silanization and filling ratio of pumice mineral on the mechanical, melt flow, water uptake and morphological properties of PLA based composites are postulated. IR analysis confirmed that surface of $\mathrm{P}$ is covered by silane coupling agent after silane treatment. Mechanical test results reveal that silanized $P$ containing PLA composites showed higher tensile strength and impact strength compared to untreated $\mathrm{P}$ samples. The optimum concentration of $P$ was obtained as $15 \mathrm{wt} \%$ in the case of tensile strength. Additions of $P$ powders resulted with slight decrease for elongation of PLA. MFR value of PLA increased with the additions of $P$ and $P(S)$. According to water absorption test, silane treated $P$ containing composites gave lower water uptake compared to untreated $P$ because of hydrophobic character of silane containing surface. SEM analysis implied that more homogeneous dispersion was observed for $\mathrm{P}(\mathrm{S})$ samples than $\mathrm{P}$ into PLA matrix. This finding is the evidence of increasing of adhesion between two phases that resulted with improvement for mechanical and physical properties of PLA based composites.

\section{References}

Akkaya, R., 2013. Uranium and thorium adsorption from aqueous solution using a novel polyhydroxyethylmethacrylate-pumice composite. Journal of Environmental Radioactivity, 120, 58-63.

Alghadi, A.M., Tirkes, S. and Tayfun, U., 2020. Mechanical, thermo-mechanical and morphological characterization of ABS based composites loaded with perlite mineral. Materials Research Express, 7, 015301.

Arbelaiz, A., Fernández, B., Ramos, J.A., Retegi, A., LlanoPonte, R. and Mondragon, I., 2005. Mechanical properties of short flax fibre bundle/polypropylene composites: Influence of matrix/fibre modification, fibre content, water uptake and recycling. Composites Science and Technology, 65(10), 1582-1592.

Bajpai, P.K., Singh, I. and Madaan, J., 2012. Development and characterization of PLA-based green composites: 
A review. Journal of Thermoplastic Composite Materials, 27, 52-81.

Bismarck, A., Baltazar, A., Jimenez, Y. and Sarikakis, K., 2006. Green composites as panacea? Socio-economic aspects of green materials. Environment, Development and Sustainability, 8, 445-463.

Bolen, W.P., 2008. Pumice and Pumicite. Minerals Yearbook, U.S. Geological Survey, Virginia, USA.

Dogan, S.D., Tayfun, U. and Dogan, M., 2016. New route for modifying cellulosic fibers with fatty acids and its application to polyethylene/jute fiber composites. Journal of Composite Materials, 50(18), 2475-2485.

Elmastas, N., 2012. Türkiye Ekonomisi için önemi giderek artan bir maden: Pomza (sünger taşı). Journal of International Social Research, 5(23), 197-206.

Eselini, N., Tirkes, S., Akar, A.O. and Tayfun, U., 2019. Production and characterization of poly (lactic acid)based biocomposites filled with basalt fiber and flax fiber hybrid. Journal of Elastomers and Plastics, DOI: 10.1177/0095244319884716.

Ge, C., Ding, P., Shi, L. and Fu, J., 2009. Isothermal crystallization kinetics and melting behavior of poly(ethyleneterephthalate)/barite nanocomposites. Journal of Polymer Science B: Polymer Physics, 47, 655-668.

Gok, A., Gode F. and Turkaslan, B.E., 2006. Synthesis and characterization of polyaniline/pumice composite. Materal Science and Engineering: B, 133(1-3), 20-25.

Han, B., Sun, Z., Chen, Y., Tian, F., Wang, X. and Lei, Q., 2009. Space charge distribution in low-density polyethylene (LDPE)/pumice composite. Proceedings of 9th International Conference on Properties and Applications of Dielectric Materials, China, 19-23.

Hatipoglu, A. and Dike, A.S., 2020. Effects of concentration and surface silanization of barite on the mechanical and physical properties of poly (lactic acid)/barite composites. Polymers and Polymer Composites, 28(2), 140-148.

Jayakrishnan, P. and Ramesan, M.T., 2016. Synthesis, characterization and properties of poly (vinyl alcohol)/chemically modified and unmodified pumice composites. Journal of Chemical and Pharmaceutical Sciences, 1, 97-104.

Kanbur, Y. and Tayfun, U., 2017. Mechanical, physical and morphological properties of polypropylene/huntite composites. Sakarya University Journal of Science, 21(5), 1045-1050.
Kanbur, Y. and Tayfun, U., 2018. Mechanical, physical and morphological properties of acidic and basic pumice containing polypropylene composites. Sakarya University Journal of Science, 22(2), 333-339.

Kilinc, K., Kanbur, Y. and Tayfun, U., 2019. Mechanical, thermo-mechanical and water uptake performance of wood flour filled polyurethane elastomer ecocomposites: influence of surface treatment of wood flour. Holzforschung, 73(4), 401-408.

Kul, A.R., Benek, V., Selcuk A. and Onursal, N., 2017. Using natural stone pumice in van region on adsorption of some textile dyes. JOTCSA, 4(2), 525.

Metin, D., Tihminhoglu, F., Balkose, D. and Ulku, S., 2004. The effect of interfacial interactions on the mechanical properties of polypropylene/natural zeolite composites. Composites Part A: Applied Science and Manufacturing, 35(1), 23-32.

Mohanty, A.K., Misra, M. and Drzal, L.T., 2002. Sustainable bio-composites from renewable resources opportunities and challenges in the green materials world. Journal of Polymer and Environment, 10, 19-26.

Murariu, M. and Dubois, P., 2016. PLA composites: From production to properties. Advanced Drug Delivery Reviews, 107, 17-46.

Oktem, G.A. and Tincer, T., 1994. Preparation and characterization of perlite-filled high- density polyethylenes: 1 . Mechanical Properties. Journal of Applied Polymer Science, 54, 1103-1114.

Ramesan, M.T., George, A., Jayakrishnan, P. and Kalaprasad, G., 2016. Role of pumice particles in the thermal, electrical and mechanical properties of poly(vinyl alcohol)/poly(vinyl pyrrolidone) composites. Journal of Thermal Analysis and Calorimetry, 126(2), 511-519.

Rasal, R. M., Janorkar, A. V. and Hirt, D. E., 2010. Poly (lactic acid) modifications. Progress in Polymer Science, 35, 338-356.

Ren, J., 2011. Biodegradable Poly (lactic acid): Synthesis, Modification, Processing and Applications. Springer, Verlag.

Rothon, R.N., 2003. Particulate-filled Polymer Composites. 2nd Edition, Rapra Ltd, UK.

Sahin, A.E., Yildiran, Y., Avcu, E., Fidan, S. and Sinmazcelik, T., 2013. Mechanical and thermal properties of pumice powder filled PPS composites. Proceedings of the 3rd International Congress, Antalya, Turkey, 2428. 
Shokoohi, S., Arefazar, A. and Khosrokhavar, R., 2008. Silane coupling agents in polymer-based reinforced composites: A review. Journal of Reinforced Plastics and Composites, 27(5), 473-485.

Silverstein, R. and Webster, F., 2006. Spectrometric Identification of Organic Compounds. Wiley, USA

Tayfun, U. and Dogan, M. 2016. Improvement the dyeability of poly(lactic acid) fiber using organoclay during melt spinning. Polymer Bulletin, 73(6), 15811593.

Tayfun, U., Dogan, M. and Bayramli, E., 2016. Influence of surface modifications of flax fiber on mechanical and flow properties of TPU based eco-composites. Journal of Natural Fibers, 13(3), 309-320.

Tayfun, U., Dogan, M. and Bayramli, E., 2017. Investigations of the flax fiber/thermoplastic polyurethane eco-composites: Influence of isocyanate modification of flax fiber surface. Polymer Composites, 38(12): 2874-2880.

Tayfun, U., Dogan, M. and Bayramli, E., 2017. Polyurethane elastomer as a matrix material for short carbon fiber reinforced thermoplastics. Anadolu University Journal of Science and Technology AApplied Sciences and Engineering, 18(3), 682-694.

Theberge, J.E., 1982. Mineral reinforced thermoplastic composites. Journal of Elastomers and Plastics, 14, 100-108.

Tian, H.Y. and Tagaya, H., 2007. Preparation, characterization and mechanical properties of the polylactide/perlite and the polylactide/ montmorillonite composites. Journal of Material Science, 42, 3244-3250.

Weber, C. J., Haugaard, V., Festersen, R. and Bertelsen, G., 2002. Production and applications of biobased packaging materials for the food industry. Food Additives and Contaminants, 19, 172-177.

Xanthos, M., 2005. Functional Fillers for Plastics. Weinheim, Wiley VCH.

Yang, R., Liu, Y., Wang, K. and Yu, J., 2003. Characterization of surface interaction of inorganic fillers with silane coupling agents. Journal of Analytical and Applied Pyrolysis, 70(2), 413-425.

Yavuz, M., Gode, F., Pehlivan, E., Ozmert, S., Sharma and Y.C., 2008. An economic removal of $\mathrm{Cu} 2+$ and $\mathrm{Cr} 3+$ on the new adsorbents: Pumice and polyacrylonitrile/pumice composite. Chemical Engineering Journal, 137(3), 453-461.
Yazicioglu, S., Arici, E. and Gonen, T., 2003. Pomza taşının kullanım alanları ve ekonomiye etkisi. F.Ü. DAUM Dergisi, 1, 118-123. 